\title{
Cultural identity formation: A personal narrative
}

\author{
Jose Carbajal ${ }^{1}$ \\ ${ }^{1}$ School of Social Work, Stephen F. Austin State University, Nacogdoches, TX, USA
}

Received 01 May 2020

Accepted for publication 15 May 2020

Published 17 December 2020

\begin{abstract}
This paper provides an autoethnography of personal experiences and perceptions of being a minoritized individual. This is the story of a professional social worker learning to adapt to social norms and expectations of self. I discuss the struggles I experienced as an adolescent and as a young adult attending college. This narrative highlights the intersection of faith and social work at moments in my professional development. It is at this intersection that this social worker learns to live a holistic life without feeling discriminated against or ashamed of his identity. I begin to actualize a reality with imperfect beings who also struggle to maintain their own identities. Thus, in this paper, I provide a snapshot of my development as a minority in the United States.
\end{abstract}

Keywords: empowerment, personal narrative, global challenge, minority

\section{Introduction}

Autoethnography is a qualitative research approach used to systematically analyze personal experiences in order to understand personal social and cultural experience (Jones et al., 2016; Padgett, 2017; Patton, 2015). I use autoethnography to reflect on the issues of racism and inequality and how they have shaped the formation of my cultural identity. I draw from my experiences and choose to use previous journal entries from my adolescence to young adulthood. These entries are raw and captured my thoughts, emotions, and social perceptions.

I started journaling when I was in fifth grade as part of a class assignment to improve my writing. As I wrote, my teacher encouraged me to write more about my personal experiences. After this class, I continued to write my personal experiences, although not on a daily or weekly basis. I wrote only when I felt I needed to write my thoughts or if something was bothering me. As I wrote these entries, I was not writing from the perspective of racism or inequality. I was writing specifically about my experience. As an adolescent, I did not have a conscious perspective on how racism impacted my life. I felt and sensed only that something was out of place or that I felt uncomfortable. Thus, I use personal journal entries to narrate these experiences and reflect on the issues of racism and inequality as I see them now.

For this paper, I draw from critical race theory, social identity theory, and narrative theory to explore and conceptualize my experiences. Critical race theory posits that racism is ordinary and it is an everyday experience for most people of color (Delgado and Stefancic, 2017; LadsonBillings, 1998). In addition, racism is perpetuated by society through disseminating stereotypes and minoritizing groups (Bonilla-Silva, 2018; Gillborn, 2015). Furthermore, the social construction of race is not biological or genetic (Templeton, 1998), and even though race is a social construct, the experience of an individual within that race is not unitary. The individual's experiences are intersectional, and the outcomes of these intersectional experiences are unique to the individual. Social identity theory helps explain how one has the need for belonging and inclusion in a social group while maintaining an individual identity distinct from these groups (Tajfel, 2010; Padilla and Perez, 2003; Stets and Burke, 2000). The individual forms a self-concept based on their membership in these social groups, and the individual's behavior is based on the relationship with these groups. Narrative theory conceptualizes the human experience through a story perspective and how an individual interprets and gives meaning to this story (Currie, 2011; Creswell and Poth, 2018). The story is about what the individual has 
experienced and the choices the individual has made based on the interpretation of these experiences. In this instance, I use a narrative autoethnography approach for the purposes of this reflection.

\section{A personal narrative}

My parents moved to the United States as young adults fleeing from a civil war in El Salvador in the 1980s. As a reference point, El Salvador is the smallest country in Central America with a population of 6.5 million people (The World Factbook, 2020; Ignacio, 1989). El Salvador has an estimated global migration of 1.6 million and a high number of Salvadorian nationals, approximately 1.4 million, live in the United States (Migration Policy Institute, 2019). The majority of Salvadorians living in the United States live in California (32\%) and Texas (15\%), with $8 \%$ residing in New York (Migration Policy Institute, 2019). Like many immigrants, my parents struggled as a working-class family. However, they were financially stable and provided adequately for the family.

I went to school in Long Island, New York. My adolescent reflections are from this context. The other reflections are from different regions in the United States, primarily when I was in the Army and college.

My first reflection begins when I was in high school. I began my college essay: "I have always felt discriminated against." Thankfully, I had a mentor who helped me communicate those feelings and write an acceptable college essay. In this essay, I wrote about my perception and experience as someone who has been minoritized. I continued to write: "Many have thought that I do not have the potential to become a true professional. Many still believe in stereotypes. When they think of young Hispanics, they only think of violence and lack of ability... I had to prove to others that I was a young Hispanic capable of succeeding and thriving in our competitive society." This reflection represents my sense of ordinary racism in my life. In one of my journals, I saw a similar entry. I was still dealing with the issue of feeling discriminated against and feeling marginalized. The entry stated, "I did not want to be Latino because I always felt left out and cheated... I felt that society was cruel for having or expecting me to be the same as if I was born in a family of wealth." Although wealth is mentioned here, the sentiment was more related to being considered a minority, and from critical race theory and social identity theory, my reflection acknowledges that my identity is beyond my social imposed race status. I wanted to belong and be included but because of the rejection I felt, I diminished my own identity.
Another example of feeling different was when I was an adolescent and my family drove to Niagara Falls for our summer vacation. I clearly remember traveling from Long Island to Niagara Falls. As we were driving north to upstate New York, we stopped for lunch at a rural restaurant. When we walked in, everyone in the restaurant simultaneously turned around and stared us down. I felt like I was under an intense hot spotlight. It was evident that this rural restaurant did not have customers from different ethnic groups. The reaction, as I interpreted it, showed a lack of cultural awareness (Marsiglia and Kulis, 2009), which made me feel unwelcome. My social identity was in conflict, as I experienced rejection rather than belongingness and inclusiveness. This experience resonates with being bilingual. In a monolingual country, instead of appreciating and encouraging bilingualism, it is discouraged, and someone who is bilingual is treated as a stranger or foreign and unfriendly. This leads to developing shame instead of pride and self-confidence or being seen as having linguistic capital (Yosso, 2005). Bilingualism made me feel like an outsider, discriminated against due to my linguistic ability.

The above entries show how I struggled to feel accepted. The perception was that because of my imposed minority status, I was an outsider and could never be an insider. The common theme was to not be myself, not to have my own identity, but to be assimilated in order to be accepted as an insider, the norm of society. These outsider and insider concepts are oppressive, as they insult one's identity. From Paulo Freire's (2014) perspective, I became conscious of my oppressed status. However, this consciousness came with difficulty, especially in college. I wrote, "I have been trying to be someone that I am not. I have been denying my identity and thus my culture." The consciousness only raised awareness of the reality of an internal cultural identity conflict between what was expected or perceived to be expected and how I tried to accommodate to the norm of society.

As an adolescent, I began to acknowledge this consciousness. My perception focused on how I was treated differently. In high school, I participated in a Congressional Debate team, a competitive interscholastic event (also called Student Congress or Legislative Debate). One of my tasks for the Student Congress was to deliver a speech so my classmates could decide whom to elect as the chair of the congressional committee. I clearly remember that, in this speech, I wrote about the legal system not being blind; even today I am astonished at my words, as were my peers and mentors. I talked about taking the blindfold off the justice lady since justice was not truly blind to color. I said that this blindness in the system was only a façade, and in practice, 
the justice system had 20/20 vision when it came to color. This is one of the entries from my journal that reflects this sentiment very well. "...there is never equality. The concept exists but not the action." Coates (2015, p.10), the author of Between the World and Me, goes even further than my reflection:

There is nothing uniquely evil in these destroyers or even in this moment. The destroyers are merely men enforcing the whims of our country, correctly interpreting its heritage and legacy. It is hard to face this. But all our phrasing-race relations, racial chasm, racial justice, racial profiling, white privilege, even white supremacy - serves to obscure that racism is a visceral experience, that it dislodges brains, blocks airways, rips muscle, extracts organs, cracks bones, breaks teeth.

There is no escaping this single reality of being minoritized in a country that does not accept you for who you are. These types of experiences could be considered micro-aggressive actions either at a conscious or subliminal level (Hook et al., 2016; Gillborn, 2015; Tajfel, 2010). Critical race theory posits that, due to the normalcy of racism and its everyday occurrence, those who experience racism are constantly fighting racial inequality (Burton et al., 2010). I constantly felt like I was fighting racial inequality, especially since I could not dismiss the notion that I was perceived as an outsider.

Between high school and college, I joined the U.S. Army. While I was in the Army, I had the opportunity to view my narrative in a different light. However, I had not planned to join the Army after high school but instead planned to attend college immediately. Therefore, I felt miserable the first two years of my four-year contract. This misery was mostly related to my desire to be in college and not in a highly structured environment. However, after two years, I realized that I could continue being miserable or adjust to the Army lifestyle; ultimately, my introspection changed my narrative and interpretation of it. I began to see that in the Army I never felt shame, rejection, or feeling less than anyone else. I felt like a valued part of a team. These feelings began to shape my minoritized identity as someone of worth. It gave me confidence that the imposed minority status I previously experienced was merely a projection from others who were insecure or unaware of their privileged status and the influence it had on those who are considered minorities (Bonilla-Silva et al., 2006; Gillborn, 2015). Thus, the Army prepared me to succeed in college and to become the social worker I am today. In fact, it was because of a friend in the Army that I decided to pursue social work. He mentioned that as a social worker, I could work almost anywhere, and he convinced me that social work was my career path. The decision to pursue social work led me directly to college after my military service contract was fulfilled.

The transition from military life to civilian (college) life was serendipitous. Since I had adjusted to the Army lifestyle, I planned to continue until I retired. However, I was informed that I was going to receive orders to go to Korea, which was not my preferred location. That is when I decided to look for a college so I could continue my studies (I already had taken 60 credit hours as a part-time student). Since I had decided to major in social work, I searched for different universities. The primary search was on universities in Texas, and I decided to apply to Baylor University because they had the dual program in social work and divinity. However, even though Baylor University was a great choice, it triggered my previous feelings of inadequacy. My selfconcept, my social identity, did not match with Baylor's social groups, and once again I felt like I was fighting racial inequalities.

Attending Baylor University, where the student profile was primarily Caucasian, was a struggle. I did not feel understood or connected, but instead I felt less than others and inadequate. Fortunately, however, there were three professors whom I regarded as ones who understood me. I felt their acceptance and desire to teach me. From a professional perspective and as an academician, my emotional injuries prevented me from feeling acceptance from some of the Baylor faculty. My narrative had been formed as an oppressed individual, and my formed adolescent social identity did not match Baylor's social groups. However, I began to learn how my wound filtered the acceptance from these professors. I had to learn about cultural humility (Foronda et al., 2016; Hook et al., 2013; Yeager and Bauer-Wu, 2013), an openness and receptivity to others in spite of my own emotional injuries. When I started attending George T. Truett Seminary, I felt that two of the professors believed in me and showed me how I was much more capable than I gave myself credit for (although, at this point, my previous social work professors had already worked through my emotional injury filter). This is the cruelty of growing up in an environment where you are considered a minority and not accepted: even when others accept you, your perception of them is that they do not understand you, especially because of those emotional, discriminatory experiences. I had to reinterpret my narrative, accepting that in this world, there are some who are truly evil, but others are just equally traumatized and insecure. Thus, my self-evaluation and self-critique required me to 
redress the social cultural mismatches (Tervalon and MurrayGarcia, 1998).

As I became a clinical social worker with theological training and integration of faith and social work, my narrative changed (Lee and Barrett, 2007). I began to reinterpret my earlier experiences and approach my social identity from a different perspective. I did not dismiss the reality of my experiences of feeling discriminated against or a sense of rejection. I began to see the role of faith in my life. I developed empathy for society's struggle, even for those who felt they had a claim to their privileged social status. That is, the struggle to belong in society is not exclusive but inclusive to all. Even those who believe they have the right to oppress others have a need to belong. Thus, faith shaped my emotional injuries and social perspective.

My clients reinforced that faith played a crucial role in their narratives as well as in how they coped with their crises. As I worked with trauma cases, I began to conceptualize a suffering model that is transcendental to individual experiences. Faith is the impetus to processing trauma. Once God is accepted as a support, the person begins to receive the grace of God in their life. The underlying point is that acting in faith is the process of receiving God's grace, which is how faith restores us. We help ourselves by receiving God's grace as we act in faith, the trauma's symptoms lose their charge, and healthy recontextualization occurs. God begins to help the person recontextualize the trauma in which suffering is embraced, not from a maladaptive perspective, but from an adaptive perspective that allows the person to reconcile a traumatic event in their narrative. The trauma is inscribed in the life story of the person instead of being isolated from the person's other experiences, which causes the traumatic triggers to persist in his or her life (Van der Kolk, 2014). Therefore, faith does not dismiss the experience, but it embraces it as a life story that needs healing; indeed, it restores individuals, not just the one who is hurting but the one who caused the hurt as well. Faith is transcendental because it crosses the boundaries of self to others in time and space. History is placed in context, and humanity's own suffering is acknowledged as needing healing as well, not just an individual's suffering.

Thus, I began to integrate faith and social work practice. The aspect of faith opened the possibility of developing cultural humility. My social self-identity was no longer attached to the societal ascription to a social group or a minoritized group. I began to change my self-concept from an individual experiencing discriminatory acts to an individual transcending time and space; that is, I was no longer part of a minoritized group. I belonged to a greater group, a faith group that encompasses all people, from all walks of life, across time and space.

The reinterpretation of my narrative using a faith perspective did not change my understanding of the need for social justice and equality (Lee and Barrett, 2007). Instead, as Paulo Freire (2014) wrote about the oppressed becoming conscious and experiencing cultural transformation, I believe I developed a critical consciousness of myself. As Coates (2015, pp.8-9) stated, "it is so easy to look away, to live with the fruits of our history and to ignore the great evil done in all of our names." However, becoming conscious and effectively transforming society requires us not to look away but to remember the fruits of our history so we can contextualize the problem.

As I reflect on my personal journey, I cannot dismiss how ineffectively we have handled racism, prejudice, and inequality. Our political actions and policies often disregard our commitment to one another as human beings. In the name of privacy or protection (however one wants to label it), all disregard the other, minorities and those marginalized. Furthermore, our political actions reflect a society that protects those with ancestral wealth, but those without this background get "the club of criminal justice" (Coates, 2015, pp.17-18). I have seen the effects of social policies in place that reinforce this sentiment. For example, my wife and I provided foster care to two little girls who were placed in this arrangement because their parents were deported due to their legal status. They experienced separation anxiety, grief, and some traumatic stress response symptoms. For the first two weeks, they had sleep disturbances. Their experience resonates with many of my clinical cases, and the children of immigrants who fear the unknown of their parents. These experiences shape their cultural identity formation. Based on my personal experience and clinical observation, the charge for us is to actualize a different society (Sobrino, 1993), one that provides an environment of kindness, civility, respect, and acceptance for all whereby we can achieve our greatest potential without feeling inadequate and less than others and live in harmony with one another.

\section{Conclusion}

As I reflect on my journal entries, for over a decade I was emotionally troubled about how I perceived society and how society perceived me. My cultural identity suffered during my adolescence and young adulthood, and it has not been easy healing from these emotional injuries. I still have to remind myself to place conversations and interactions in context. I suspect others have similar experiences to those of my identity formation. Nevertheless, I am hopeful because I 
have been able to work through my narrative, but I am also saddened with how long we have denied the existence of institutional racism and discrimination. Those with privilege have been reticent to accept and use their influence to change these racist social structures. Racism and inequality have denied basic human rights to others, and until we are able to acknowledge that institutions have been formed to oppress and isolate those who do not mirror the majority, we will not overcome institutional and structural racism. As social workers, it is our responsibility to help those who are marginalized and need access to services to meet their basic needs. This is an ethical responsibility regardless of our upbringing and values. As social workers, it is our responsibility to make sure everyone's human rights are granted and protected. We are the conscience of society! I hope we continue to strive to rectify years of basic human rights violations and provide a welcoming environment to everyone, as we apply our social work values and principles.

\section{References}

Bonilla-Silva, E. (2018) Racism without racists: Color-blind racism and the persistence of racial inequality in america. $5^{\text {th }}$ edn. Lanham, MD: Rowman \& Littlefield.

Bonilla-Silva, E., Goar, C. and Embrick, D.G. (2006) 'When whites flock together: The social psychology of white habitus', Critical Sociology, 32(2-3), pp. 229-253.

Burton, L. M., Bonilla-Silva, E., Ray, V., Buckelew, R. and Hordge Freeman, E. (2010) 'Critical race theories, colorism, and the decade's research on families of color', Journal of Marriage and Family, 72(3), pp. 440459.

Creswell, J.W. and Poth, C. (2018) Qualitative inquiry and research design. 4 th edn. Los Angeles, CA: SAGE.

Coates, T-N. (2015) Between the world and me. New York, NY: Random House Publishing Group. Kindle Edition.

Currie, M. (2011) Postmodern narrative theory. $2^{\text {nd }}$ edn. New York, NY: Palgrave Macmillan.

Delgado, R. and Stefancic, J. (2017) Critical race theory: An introduction. $3^{\text {rd }}$ edn. New York, NY: New York University Press.

Foronda, C., Baptiste, D.L., Reinholdt, M.M. and Ousman, K. (2016) 'Cultural humility: A concept analysis', Journal of Transcultural Nursing, 27(3), pp. 210-217.

Freire, P. (2014) Pedagogy of hope: Reliving of the oppressed (Translated by Robert R. Barr). New York, NY: Bloomsbury.
Gillborn, D. (2015) 'Intersectionality, critical race theory, and the primacy of racism: Race, class, gender, and disability in education', Qualitative Inquiry, 21(3), pp. 277-287.

Hook, J.N., Davis, D.E., Owen, J., Worthington Jr, E.L. and Utsey, S.O. (2013) 'Cultural humility: Measuring openness to culturally diverse clients', Journal of Counseling Psychology, 60(3), pp. 353-366.

Hook, J.N., Farrell, J.E., Davis, D.E., DeBlaere, C., Van Tongeren, D.R. and Utsey, S.O. (2016) 'Cultural humility and racial microaggressions in counseling', Journal of Counseling Psychology, 63(3), pp. 269-277.

Ignacio, M-B. (1989) 'Political violence and war as causes of psychosocial trauma in El Salvador', International Journal of Mental Health, 18(1), pp. 3-20.

Jones, S.H., Adams, T.E. and Ellis, C. (Eds.). (2016) Handbook of autoethnography. New York, NY: Routledge.

Ladson-Billings, G. (1998) 'Just what is critical race theory and what's it doing in a nice field like education?' International Journal of Qualitative Studies in Education, 11(1), pp. 7-24.

Lee, E.K.O. and Barrett, C. (2007) 'Integrating spirituality, faith, and social justice in social work practice and education: A pilot study', Journal of Religion \& Spirituality in Social Work: Social Thought, 26(2), pp. 121.

Marsiglia, F.F. and Kulis, S. (2009) Diversity, oppression, and change: Culturally grounded social work. $2^{\text {nd }}$ edn. New York, NY: Oxford University Press.

Migration Policy Institute (2019) Central American Immigrants in the United States. Available at: http://www.migrationpolicy.org/article/central-americanimmigrants-united-states (Accessed: 1 August 2019).

Padilla, A.M. and Perez, W. (2003) 'Acculturation, social identity, and social cognition: A new perspective', Hispanic Journal of Behavioral Sciences, 25(1), pp. 35-55.

Padgett, D.K. (2017) Qualitative methods in social work research. $3^{\text {rd }}$ edn. Thousand Oaks, CA: SAGE.

Patton, M.Q. (2015) Qualitative evaluation and research methods. $4^{\text {th }}$ edn. Thousand Oaks, CA: SAGE.

Sobrino, J. (1993) Jesus the liberator: A historical theological reading of Jesus of Nazareth (Translated by Paul Burns). New York, NY: Orbis Books, Maryknoll. 
Stets, J.E. and Burke, P.J. (2000) 'Identity theory and social identity theory', Social Psychology Quarterly, 63(3), pp. 224-237.

Tajfel, H. (Ed.). (2010). Social identity and intergroup relations. New York, NY: Cambridge University Press.

Templeton, A.R. (1998) 'Human races: A genetic and evolutionary perspective', American Anthropologist, 100(3), pp. 632-650.

Tervalon, M. and Murray-Garcia, J. (1998) 'Cultural humility versus cultural competence: A critical distinction in defining physician training outcomes in multicultural education', Journal of Health Care for the Poor and Underserved, 9(2), pp. 117-125.

The World Factbook 2020 (2020) El Salvador. Washington, DC: Central Intelligence Agency. Available at: https://www.cia.gov/library/publications/the-worldfactbook/geos/es.html\#top (Accessed: 14 August 2020).

Van der Kolk, B.A. (2014) The body keeps the score: Brain, mind, and body in the healing of trauma. New York, NY: Penguin Books.

Yeager, K.A. and Bauer-Wu, S. (2013) 'Cultural humility: Essential foundation for clinical researchers', Applied Nursing Research, 26(4), pp. 251-256.

Yosso, T.J. (2005) 'Whose culture has capital? A critical race theory discussion of community cultural wealth', Race Ethnicity and Education, 8(1), pp. 69-91, doi:10.1080/1361332052000341006 